\title{
スパッタレスレーザー金属積層造形法の開発
}

\author{
佐藤 雄二, 塚本 雅裕 \\ 大阪大学 接合科学研究所 ( $565-0047$ 大阪府茨木市美穂が丘11-1)
}

\section{Development of Sputter-Free Selective Laser Melting}

\author{
Yuji SATO and Masahiro TSUKAMOTO \\ Joining and Welding Research Institute, Osaka University, 11-1 Mihogaoka Ibaraki-shi, Osaka 567-0047
}

(Received December 20, 2017)

\begin{abstract}
An additive manufacturing (AM) method has been attracting interest due to its process in free-form fabrication. Selective laser melting (SLM), one AM technology that is useful for direct and complicated shape formation, forms a 3D material by building it layer by layer from a metal powder. This paper reviews the recent progress in selective laser melting, which is an additive manufacturing technology. We developed sputter-free fabrication for SLM in a vacuum to minimize the surface roughness to $0.40 \mu \mathrm{m}$ at a laser scanning speed of $10 \mathrm{~mm} / \mathrm{s}$.
\end{abstract}

Key Words: Additive manufacturing, Selective laser melting, Ti, Sputter-free

1. はじめに

金属の付加製造技術 (Additive Manufacturing: AM)の一 つであるレーザー金属積層造形法 (Selective Laser Melting: SLM) またはレーザー粉末床溶融法(Laser Powder Bed Fusion: L-PBF) は, 3D-CADデータを元に金属粉末か ら3次元形状の製品を直接造形できる加工方法である。 近年では金属の3Dプリンタと呼ばれている技術であ る. 熱源には局所的・選択的に加熱できるレーザーが用 いられ, 一層毎に金属粉末を溶融・凝固して2D形状を 作り，これを繰り返し積み上げて3D形状を形成する。 従来の切削加工や塑性加工, 鋳造加工では製造出来ない 複雑形状の製品を作製できる。これらの特徵を生かし て, 金型や機械部品の試作・開発, 小ロット部品の製 造, 航空宇宙分野のブラケットや燃料噴射装置, ケーシ ングなど，医療分野ではカスタムオーダーメイドが必要 となる人工関節等の整形外科用インプラントや，歯科用 ブリッジなどが応用例として挙げられている。造形可能 な材料には, $\mathrm{Ni}$ 系合金, インコネル, ハステロイ, ステ ンレス, チタン, チタン合金, アルミニウム合金など数 多くの材料が報告されており，当該技術の研究開発およ び応用研究が世界各国で進められている ${ }^{1-8)}$. SLMの装 置メーカとしては, EOS社, SLM Solutions社, Concept Laser社がリードしており，これらの企業は，すべてド イツ企業である。また，2016年にTRUMPF社，2017年2 月にDMG Mori社がそれぞれSLM装置をリリースするな ど，ドイツ企業の活躍が目立つ。一方，アメリカでは，
General Electric社が，SLM法の装置メーカConcept Laser 社と熱源に電子ビームを用いた造形装置を扱う ARCAM 社を買収し，新規プロセスの開発や技術開発，その応用 開発に力を入れている。2017年2月に開催されたWorkshop on LAM 2017では, 「パウダーベースで飛行機を作 る夢を実現する」と講演で発表し，2017年11月には，ド イッ・フランクフルトで開催された展示会formnext 2017 にて直径 $1 \mathrm{~m} の$ 造形を可能とするGE Additive BETAマシ ンをお披露目するなどGE社の話題にこと欠かない．米 国では，ローレンスリバモア国立研究所のグループが, SLM法における粉末の溶融凝固現象を, 数值計算を駆 使して詳細に解析し，レーザーが粉末に照射された時に 発生するスパッタリングの発生機構を解明してい る ${ }^{9,10)}$. さらにこれら数值計算結果を基にステンレス 鋼316Lを造形した結果, 通常のステンレス鋼 (SUS316L)の2-3倍の強度を有し, 且つ従来のステンレ 又鋼の延性と同等の值を併せ持った造形に成功したと報 告があった ${ }^{11)}$.

2017年6月にミュンヘンで開催された国際会議Lasers in ManufacturingにてSLM Solutions社からHull \& Coreで インコネル718を造形した結果, 単結晶の造形に成功し たと報告があった ${ }^{12)}$ 。会議ではプロジェクト進行中とい うことで, 詳細な造形パラメータの開示が無かったが, これらの報告は, SLMプロセスにおいて材料組織まで 精密に制御可能であることを意味する。

国内では，技術研究組合次世代3D 積層造形技術総合 開発機構が国家プロジェクトとして立ち上がり次世代産 
業用3Dプリンタの開発を産・官・学が連携して開発を 進めている。このようにLAM分野の研究開発は, 国内 外で活発に進められている事がわかる。我々は，イノ ベーション創造プログラム (SIP)/革新的設計生産技術/高 付加価值設計・製造を実現するレーザーコーティングプ ロジェクトを推進しており，この中で金属の溶融凝固現 象の解明とスパッタレス金属溶融法の開発を進めてい る。一般に, 金属粉末にレーザーが照射されると, 粉末 でレーザーが吸収されて溶融するが，同時にスパッタリ ングと呼ばれる粉末の飛散現象が発生する。スパッタリ ングは，積層造形プロセスにおいて造形効率を低くする だけでなく，造形内部に空孔が形成されてしまい，相対 密度が小さくなってしまう等の問題の一因となる。そ己 で我々は，スパッタリングの発生を抑えたスパッタレス SLM法を開発した ${ }^{13-15)}$. 次項にてスパッタレスSLM法に ついて詳細を述べる。

\section{SLM法よる造形方法}

SLM装置の概略図をFig. 1 に示す。レーザーには, 高 出力かつビーム品質が高く, しかも光ファイバでレー ザー光を伝送できるYbファイバレーザーが最も多く採 用されている. 光ファイバから出射されたレーザー光 は，2軸あるいは3軸のガルバノミラーに導光され，集光 レンズを介してパウダーベッドに掃引照射される。

Fig. 1 に示す様に, 材料粉末は, ローラーを用いて造形 面に任意の厚さに均一に敷き均し，その状態でレーザー を掃引照射して, 材料粉末を溶融・凝固して2Dの造形 物を形成させる。次に任意の積層厚だけ造形面を下降し て，再びローラーで粉末を供給し，レーザーを照射す る。これを繰り返して立体の造形物を形成する。積層厚 さは各装置によって異なるが約 $50 \mu \mathrm{m}-100 \mu \mathrm{m}$ である. 材料粉末はローラータイプあるいはスキージタイプのブ レードで搬送するので, 流動性の高いガスアトマイズで 作製した球状の粒径 $30 \mu \mathrm{m}$ 程度の粉末を用いている。
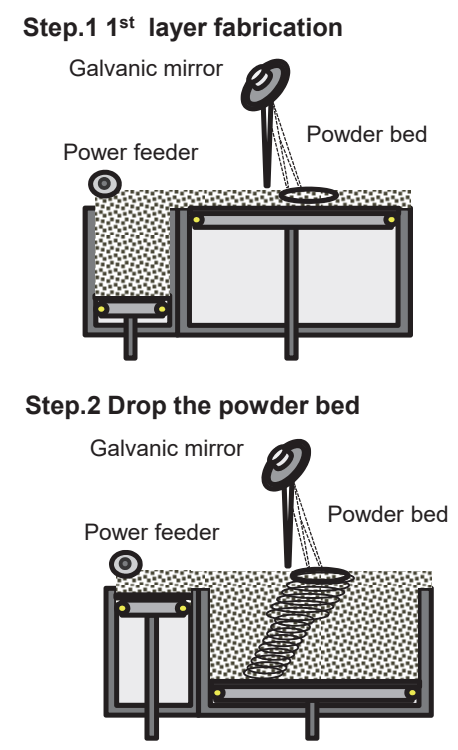

Fig. 1 Principle of SLM.

\section{3.スパッタレスSLM法を用いたTiの造形}

一般に，チタン合金(Ti-6Al-4V:Ti64)は，軽量，非磁 性，耐食性等，優れた機械的特性や生体適合性を有する ため, インプラントや人工骨などの高組織代替材料とし て臨床応用されている。しかし，チタン合金は難削材料 であり, 従来の切削加工では, 生体由来のバイオニック 構造などの複雑形状を模すことは難しい，そこでSLM 法を用いてTi64の造形を試みた。Fig. 2 にTi64粉末の SEM像を示す。Ti64粉末は, (株)大阪チタニウムテク) ロジーズ社製のTILOP64-45，前述したようにガスアト マイズ製である。粒度は，正規分布で，粒径の中心 值2 $6 \mu \mathrm{m}$ ，標準偏差 $12 \mu \mathrm{m}$ であった。

次に, スパッタレスSLM装置をFig. 3 に示す。本装置 はレーザー発振器および伝送光学系, 制御盤, 真空チャ ンバーで構成されている. Fig. 3(a) に装置写真, (b)に 装置の概略図を示す。レーザーには, 波長 $1084 \mathrm{~nm}$, 最

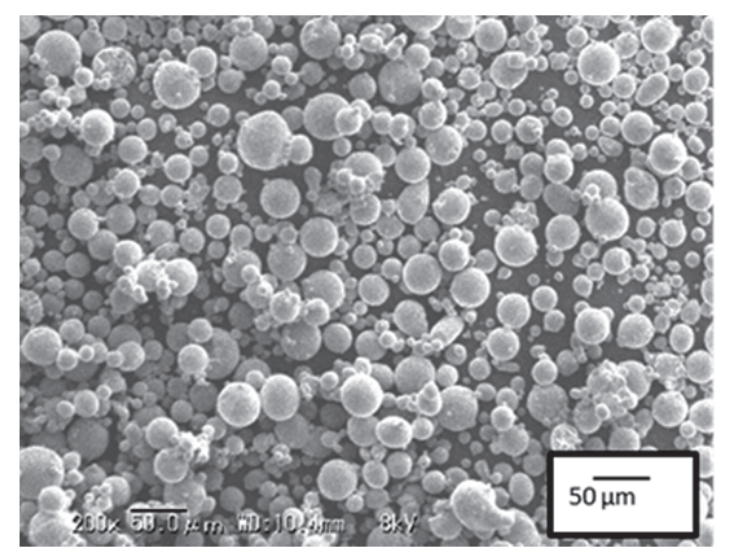

Fig. 2 Ti64 Powder for SLM.

(a)
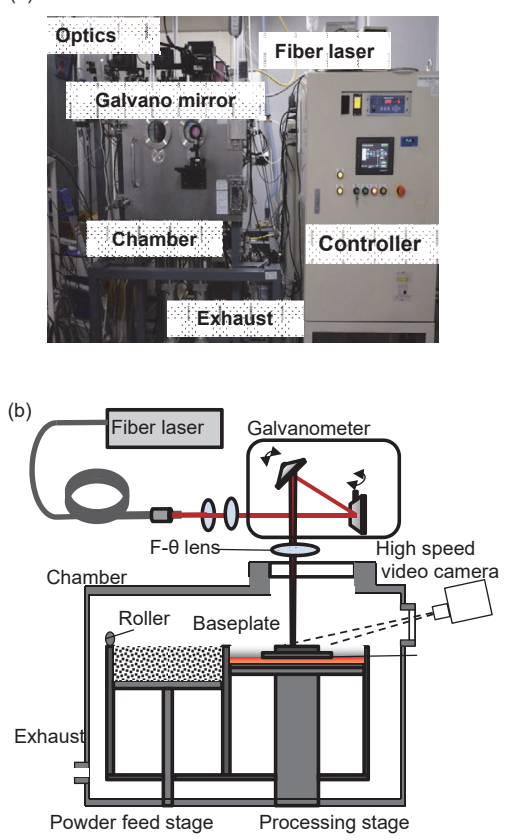

Fig. 3 Experimental step for selective laser melting in vacuum in (a) photo image and (b) schematic diagram of SLM in vacuum. 
大出力 $300 \mathrm{~W}$ Wシングルモードファイバレーザー (FITEL, Furukawa Electric Co.) を採用した。出射したレー ザーは，伝送光学系を用いて2軸制御型ガルバノミラー (CANNON. Inc) とF- $\theta$ レンズに導光し, 真空チャンバー 内の造形ステージに掃引照射する。このときレーザース ポット径は $1 / e^{2} て ゙ 150 \mu \mathrm{m}$ に調整した。 大きな特徴として は, 真空チャンバー内で造形することが出来るので, ガ スのコンタミネーションや酸化性の高い粉末, たとえば チタンの造形などが出来ることである。原料粉末である Ti64 粉末をパウダーフィーダーに設置し, 真空チャン バーを $5.0 \times 10^{-3} \mathrm{~Pa}$ ま゙真空排気する。造形ステージで あるベースプレートを積層ピッチ分下降させ, Ti64粉末 をリコータで均し，任意の厚さの粉末をパウダーベッド に敷き均す (Fig. 3(b))。この状態でレーザーを照射す る ${ }^{13)}$. レーザーの掃引方法は, Fig. 4 に示すようにリニ アラスタースキャン方式を採用し10 mm × $10 \mathrm{~mm} \times$ $0.1 \mathrm{~mm}$ の造形を行った ${ }^{14)}$.

\section{1 高速度ビデオカメラによるTi6Al4V 粉末の溶融挙 動観察}

Fig. 5 にTi64粉末にレーザーを照射したときの溶融凝 固過程を高速度ビデオカメラで撮影した像を示す。レー ザー照射条件は，レーザー出力 $150 \mathrm{~W}$ ，ハッチング距 離50 $\mu \mathrm{m}$ ，掃引速度をFig. 5 (a) $10 \mathrm{~mm} / \mathrm{s}, \quad$ (b) $25 \mathrm{~mm} / \mathrm{s}$, (c) $50 \mathrm{~mm} / \mathrm{s}$ ，(d) $100 \mathrm{~mm} / \mathrm{s}$ とした. $t=80 \mathrm{~ms}$ でレーザーが照 射されると, $t=80 \mathrm{~ms}$ でTi64粉末表面でレーザーが吸収 され, $t=160 \mathrm{~ms}$ で溶融池が形成され, その後, $t=$ $240 \mathrm{~ms}$ では凝固が起こり, 熱が拡散して自然冷却されて いる事がわかる。 $240 \mathrm{~ms}$ 以降では，これらの様子が繰返 し起こる様子が観察された. Fig. 5(c)，（d）のように掃 引速度が50 mm/s以上になると, 粉末にレーザーが照射 されると, 即座にスパッタリングが発生しているのが確 認できる. 一方, Fig. 5 (b)の様に掃引速度が $25 \mathrm{~mm} / \mathrm{s}$ 以 下になるとスパッタリングの発生量は少なくなり,

Fig. 5 (a) 10 mm/sのときは, スパッタリングは殆ど観察 されなかった，材料粉末の表面には， $\mathrm{H}_{2} \mathrm{O}, \mathrm{N}_{2}, \mathrm{O}_{2}$ など が吸着しておりレーザーが照射されると, 粉末が蒸発す るのと同時にこれらの吸着物質も同時に放出される ${ }^{16)}$.

掃引速度が $50 \mathrm{~mm} / \mathrm{s}$ 以上に速い時には，レーザーが照射 されると粉末の蒸発と吸着物質の放出が同時に起こり, 体積が膨張してスパッタリングが起こる。一方, 掃引速 度が遅い $10 \mathrm{~mm} / \mathrm{s}$ では，レーザーのスポットはガウシア

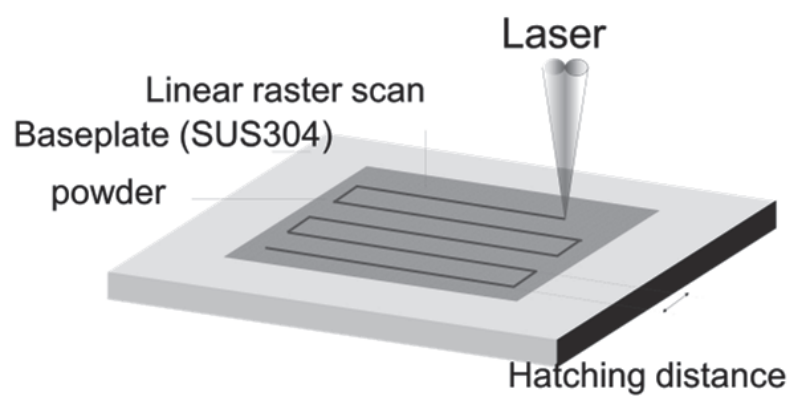

Fig. 4 Schematic diagram of the laser scanning strategy.

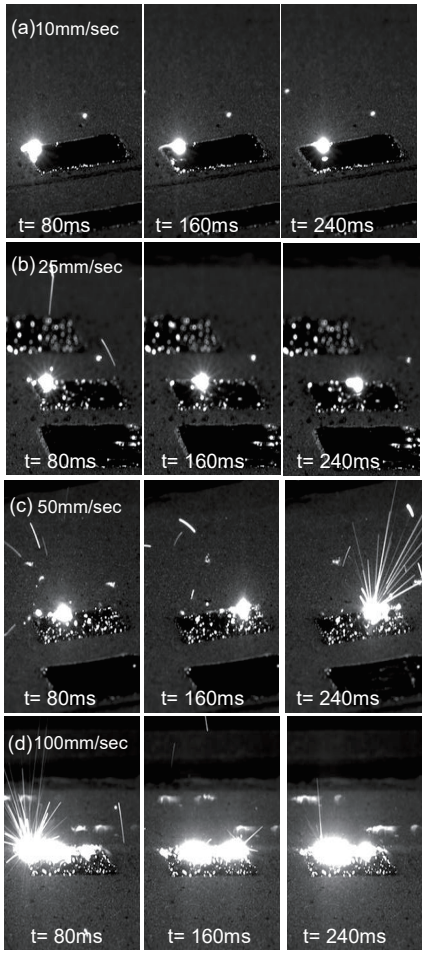

Fig. 5 Melting and solidification processes captured with a high speed video camera at the laser scanning speed of (a) $10 \mathrm{~mm} / \mathrm{s}$, (b) $25 \mathrm{~mm} / \mathrm{s}$, (c) $50 \mathrm{~mm} / \mathrm{s}$ and (d) $100 \mathrm{~mm} / \mathrm{s}$.

ンビームであるため, レーザー強度の低い部分で粉末が 予備加熱され，最初に吸着物質の放出が起こる。その 後, 強度の高い部分が照射されて粉末の溶融および蒸発 が起こる。このガウシアンビームの予熱効果によって, 局所的な体積膨張が小さくなり，スパッタリングが抑制 されたものと考えられる。

\section{2 造形したTi合金表面解析}

触針式形状測定装置を用いて, 造形サンプルの表面粗 さを測定した，算術平均粗さ $R_{\mathrm{a}}$ は，式 (1)に示す様に粗 さ曲線 $f(x)$ からその平均線の方向に基準長さlに対する 平均線から測定曲線までの偏差の絶対值を合計し, 平均 值とした。

$$
R_{a}=\frac{1}{l} \int_{o}^{\ell} f(x) d x
$$

Fig. 6 にレーザー掃引速度に対する造形したTi64板表 面の表面粗さ測定結果を示す。レーザー出力は, $150 \mathrm{~W}$ と固定し，レーザー掃引速度は，5-100 mm/s と変化させ た。表面粗さ $R_{\mathrm{a}}$ は、レーザー掃引速度が速くなるにした がって大きくなることがわかる。これは前述したスパッ タリングと相関しており，スパッタリングの発生量が増 加すると表面粗さ $R_{\mathrm{a}}$ が大きくなることから， スパッタリ ング量に表面粗さが依存している事を示唆している. Fig. 7 にレーザー掃引速度 $10 \mathrm{~mm} / \mathrm{s}$ と $50 \mathrm{~mm} / \mathrm{s}$ のンプル 写真および断面観察の結果を示す。掃引速度が50 mm/s

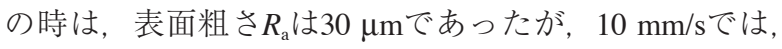
表面粗さ $R_{\mathrm{a}}$ は, $0.62 \mu \mathrm{m}$ と最も小さくなった。ささらに, 


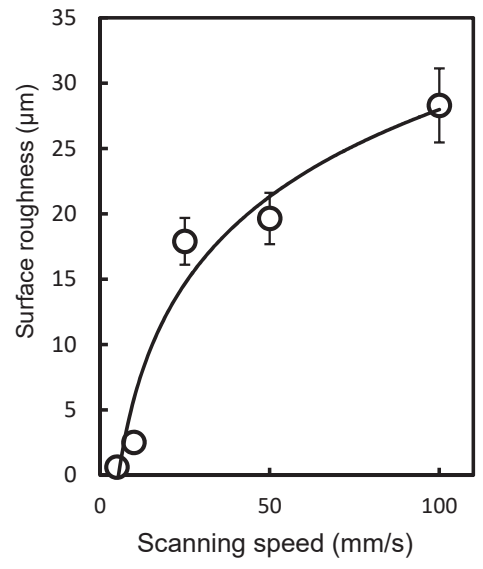

Fig. 6 Correlation between the laser scanning speed and surface roughness Ra of the fabricated Ti64 plate surface.

(a)

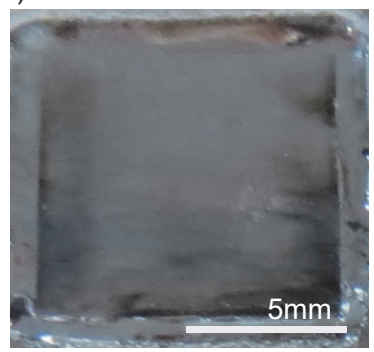

(b)

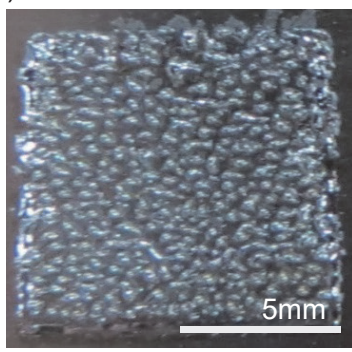

Fig. 7 Optical images of the Ti64 plate fabricated with a scanning speed of (a) $10 \mathrm{~mm} / \mathrm{s}$ and (b) $50 \mathrm{~mm} / \mathrm{s}$.

これらのサンプルをレーザーの掃引方向に垂直に切断 し, 樹脂埋め研磨を行った. Fig. 8 に断面の顕微鏡観察

(a)

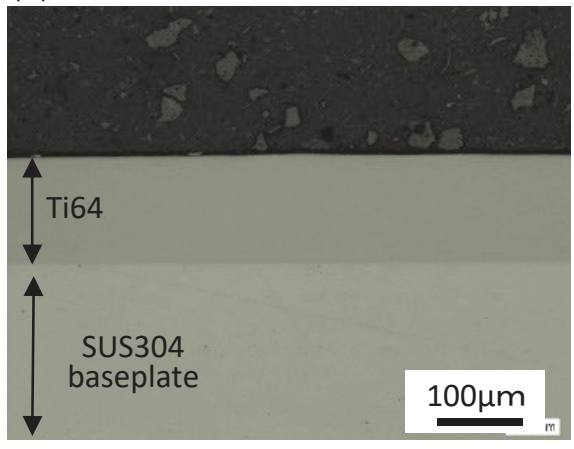

(b)

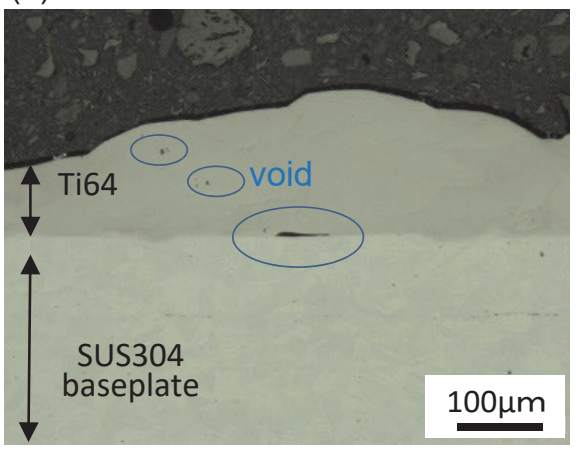

Fig. 8 Microscope images of cross section in (a) $10 \mathrm{~mm} / \mathrm{s}$ and (b) $50 \mathrm{~mm} / \mathrm{s}^{14)}$
結果を示す．掃引速度 $50 \mathrm{~mm} / \mathrm{s}$ ときには，基板とTi64 層の間やTi層内にボイドが発生しているのがわかる。一 方，レーザー掃引速度が $10 \mathrm{~mm} / \mathrm{s}$ の時では，ボイドや空 孔は現れず，緻密な造形が出来ている事がわかった。

$$
\text { 4. まとめ }
$$

本報では，レーザー金属積層造形法に焦点を当てて， 最新の研究開発動向およびスパッタリングの発生を抑制 したスパッタレスSLMの一部を紹介した。レーザー金 属積層造形技術は，設計の自由度が高くなることに加 え, 造形物の材料組織が制御出来, しかも単結晶材料の 造形が可能となれば，部位ごとに材料組織変えられるよ うな真の意味のテーラーメードものつくりを実現する技 術となり得る。本報で紹介出来なかった技術や応用例も 数多くあり，今後ますますレーザー金属積層造形技術の 進展が期待される。本報がレーザー金属積層造形技術を 使用するための一助になれば幸いである.

\section{謝 辞}

本研究は，国立研究開発法人新エネルギー・産業技術 総合開発機構(NEDO)の委託事業,戦略的イノベーショ ン創造プログラム $(\mathrm{SIP}) /$ 革新的設計生産技術「高付加価 值設計・製造を実現するレーザーコーティング技術の研 究開発」の助成を受けて実施したものである.

\section{参考文献}

1) E. C. Santos, M. Shiomi, K. Osakada, and T. Laoui: Int. J. Mach. Tools and Manufacture 46 (2006) 1459.

2) B. Zhang, N. E. Feinech, H. L. Liao, and C. Coddet: J. Mater. Sci Technol. 29 (2013) 757.

3) D. Gu, Y. Shen, and Z. Lu: Mat. Lett. 6 (2009) 1577.

4) Z. Wang, K. Guan, M. Gao, X. Li, X. Chen, and X. Zeng: J. Alloy and Compounds 513 (2012) 518.

5) Q. Jia and D. Gu: J. Alloy and Compounds 585 (2014) 713.

6) I. Yadroitsev, P. Krakhmalev, I. Yadroitsava, S. Johansson, and I. Smurov: J. Mat. Processing Technol. 213 (2013) 606.

7) J. Sun, Y. Yang, and D. Wang: Materials and Design 49 (2013) 545.

8) B. Zhang, H. Liao, and C. Coddet: Vacuum 95 (2013) 25.

9) M. J. Matthews, G. Guss, S. A. Khairallah, A. r M. Rubenchik, P. J. Depond, and W. E. King: Acta Materia 114 (2016) 33.

10) S. Ly, A. M. Rubenchic, S. Khairallah, G. Guss, and M. J. Matthews: Sci. Rep. 74085 (2017) 1.

11) Y. MorrisWang, Thomas Voisin, Joseph T. McKeown, Jianchao Ye, Nicholas P. Calta1, Zan Li, Z. Zeng, Y. Zhang, W. Chen, T. T. Roehling, et al.: Nature Materials (2017) Advanced online publication, DOI: 10.1038/NMAT502.

12) J. Chen, D. Schwarze, and T. Niendorf: Proc. Lasers in Manufacturing Conference (2017).

13) Y. Sato, M. Tsukamoto, and Y. Yamashita: Appl. Phys. B 119 (2015) 545.

14) Y. Sato, M. Tsukamoto, S. Masuno, Y. Yamashita, D. Tanigawa, and N. Abe: Appl. Phys. A 122 (2016) 439.

15) Y. Sato, M. Tsukamoto, Y. Yamashita, S. Masuno, K. Yamashita, S. Yamagata, and R. Higashino: IEEJ Trans. Fundamentals and Mat. 135 (2017) 265

16) S. Nakano, N. Sato, and T. Shimizu: Gas Turbine Soc. Jpn. 42 (2014) 433 